\title{
Upregulation of IL-17A/F from human lung tissue explants with cigarette smoke exposure: implications for COPD
}

Ying Chang ${ }^{1,2^{*}+}$, Laila Al-Alwan ${ }^{1 \dagger}$, Sama Alshakfa', Severine Audusseau ${ }^{1}$, Andrea Karen Mogas ${ }^{1}$, Fazila Chouiali ${ }^{1}$, Parameswaran Nair ${ }^{3}$, Carolyn J Baglole ${ }^{1}$, Qutayba Hamid ${ }^{1}$ and David H Eidelman ${ }^{1}$

\begin{abstract}
Background: Chronic obstructive pulmonary disease (COPD) is an inflammatory disorder marked by relative resistance to steroids. The IL-17 superfamily, which mediates cross-talk between the adaptive and innate immune systems, has been associated with diminished responses to steroids. Increasing evidence supports elevated IL-17 expression in the lung of COPD subjects. However, whether cells of the immune system (systemic) and/or local lung cells are contributing to the elevated IL-17 remains unclear. To address this issue, we utilized a human parenchymal lung tissue explant culture system with cigarette smoke exposure to investigate the expression of IL-17 and the mechanisms involved.

Methods: Parenchymal lung tissue removed from 10 non-COPD and 8 COPD patients was sectioned and cultured with different concentrations of cigarette smoke extract (CSE) for 3 or 6 hours. Tissue viability was evaluated by LDH (lactate dehydrogenase) in culture supernatants. Western blot and real-time PCR were performed to evaluate IL-17A/F expression. To investigate the mechanisms, pharmacological inhibitors for MAPK p38, ERK1/2, NF-KB and PI3K pathways were added into the culture media.

Results: No tissue damage was observed after the cigarette smoke exposure for $3 \mathrm{~h}$ or $6 \mathrm{~h}$ compared with the control media. At the protein level, the expression of both IL-17A ( $2.4 \pm 0.6$ fold) and IL-17 F ( $3.7 \pm 0.7$ fold) in the tissue from non-COPD subjects was significantly increased by $5 \%$ of CSE at $3 \mathrm{~h}$. For COPD subjects, IL-17A/F expression were significantly increased only at $6 \mathrm{~h}$ with 10\% of CSE (IL-17A: $4.2 \pm 0.8$ fold; IL-17 F: $3.3 \pm 0.8$ fold). The increased expression of IL-17A/F is also regulated at the mRNA level. The inhibitors for NF-KB and PI3K pathways significantly inhibited CSE-induced IL-17A/F expression from lung tissue of non-COPD subjects.

Conclusions: We found the evidence that the expression of both IL-17A and IL-17 F is increased by the cigarette smoke exposure in explants from both non-COPD and COPD subjects, supporting that local lung cells contribute IL-17 production. The elevated IL-17A/F expression is dependent on NF-KB and PI3K pathways. These observations add to the growing evidence which suggests that Th17 cytokines play a significant role in COPD.
\end{abstract}

Keywords: COPD, IL-17, Cigarette smoke, Tissue explants

\footnotetext{
* Correspondence: changyingcn@hotmail.com

${ }^{\dagger}$ Equal contributors

${ }^{1}$ Meakins-Christie Laboratories and Respiratory Division, McGill University

Health Centre and Department of Medicine, McGill University, Montreal,

Quebec, Canada

${ }^{2}$ Center for Translational Medicine, The Key Laboratory of Biomedical

Information Engineering of Ministry of Education, School of Life Science and

Technology and Frontier Institute of Science and Technology, Xi'an Jiaotong

University, Xi'an, China

Full list of author information is available at the end of the article
}

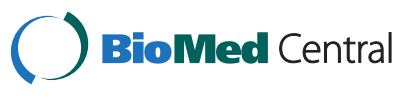

(c) 2014 Chang et al.; licensee BioMed Central Ltd. This is an Open Access article distributed under the terms of the Creative Commons Attribution License (http://creativecommons.org/licenses/by/4.0), which permits unrestricted use, distribution, and reproduction in any medium, provided the original work is properly credited. The Creative Commons Public Domain Dedication waiver (http://creativecommons.org/publicdomain/zero/1.0/) applies to the data made available in this article, unless otherwise stated. 


\section{Background}

Chronic obstructive pulmonary disease (COPD) is a progressive, irreversible chronic inflammatory disorder that is caused predominantly by cigarette smoking and is one of the leading causes of mortality globally [1]. The inflammatory response in the lungs of COPD patients is strongly linked to tissue destruction and alveolar airspace enlargement, which lead to disease progression [2]. Recent findings concerning the innate and acquired immune responses in COPD have led to the suggestion that there is an autoimmune component to its pathogenesis $[3,4]$. The mechanism by which cigarette smoke causes COPD in susceptible individuals is complex, but involves both aberrant, chronic inflammation coupled with the loss of lung structural cells due to heightened apoptosis.

The IL-17 cytokine superfamily triggers production of numerous chemokines, resulting in neutrophil and macrophage recruitment and subsequent pathogen clearance. IL17 is key to defense against bacteria and fungi, mediating cross-talk between the adaptive and innate immune systems [5]. IL-17A can influence expression of mucin (MUC5AC), a hallmark of chronic airway diseases including COPD, in human bronchial epithelial cells [6]. Furthermore, transgenic over expression of IL-17A in the alveoli of murine lung induces inflammation with a COPD-like phenotype [7]. Elevated IL-17A secretion has been reported to be present in the bronchial mucosa of COPD patients [8]. In addition, given the possible importance of IL-17A in autoimmunity [7], it is of interest to note the growing evidence that autoimmunity may contribute to the pathogenesis of COPD $[3,9]$. Our previous study has demonstrated the elevated IL$17 \mathrm{~A} / \mathrm{F}$ expression in airways of COPD patients compared to control subjects, and $\mathrm{CD}^{+} \mathrm{T}$ cells are a major cellular source [10]. However, whether the elevation of IL-17 is dependent on the local lung immune and structural cells or the recruitment of systemic immune cells remains unclear.

To address these questions we utilized tissue explants, widely used in cellular biology because of the preservation of histotypic relationship between cells in the tissue without any disturbance of the cellular or tissue architecture caused by other methods utilizing enzymatic, chemical or mechanical separation [11]. By exposing explanted lung tissue to cigarette smoke, we can detect whether cigarette smoke itself has an effect on local lung immune and structural cells. Using this approach, we found that cigarette smoke exposure promoted IL-17A/F expression of lung explants from both COPD and non-COPD subjects quickly, suggesting parenchymal tissue is an important source of IL-17A/F in individuals who smoke.

\section{Methods}

Subjects

Parenchymal lung tissue was removed from 10 nonCOPD and 8 COPD patients undergoing thoracic surgery at St. Joseph's Healthcare Hamilton, Ontario, with the collaboration of the Division of Thoracic Surgery and the Department of Pathology. The COPD patients were eligible for this study if they met the following criteria: age $\geq 50$ and $\leq 76$ years; smoking history ( $\geq 20$ pack-years); post-bronchodilator $\mathrm{FEV}_{1} \geq 25 \%$ of predicted value and post-bronchodilator $\mathrm{FEV}_{1} /$ forced vital capacity (FVC) $\leq 0.70$; no history of asthma, atopy (as assessed by an allergy skin prick test during screening) or any other active lung disease. Patients on home oxygen or with raised carbon dioxide tension $(>44 \mathrm{mmHg}), \alpha_{1}$-antitrypsin deficiency, recent exacerbation (in the last 4 weeks), an uncontrolled medical condition or hypersensitivity to inhaled corticosteroids and bronchodilators were not eligible for the study. Patient characteristics are in Table 1. This study was conducted in accordance with the amended Declaration of Helsinki. Local institutional review boards or independent ethics committees approved the protocol, and written informed consent was obtained from all patients. The experimental procedures were performed with ethical approval from the Research Ethics Boards of St. Joseph's Healthcare, McMaster University.

\section{Tissue explants}

Tissue specimens were immediately placed in Perfadex lung transplant solution on ice for transportation. Upon arrival, the tissue was placed in Bicarbonate Buffered Culture Medium (BCM) containing with $20 \mathrm{ml} / \mathrm{L}$ of amino acid supplement, $10 \mathrm{ml} / \mathrm{L}$ of sodium pyruvate, $10 \mathrm{ml} / \mathrm{L}$ of vitamin supplement, $50 \mu \mathrm{g} / \mathrm{ml}$ of gentamycin, $0.1 \mu \mathrm{g} / \mathrm{ml}$ of

Table 1 Clinical characteristics of COPD and control subjects

\begin{tabular}{lll}
\hline & COPD & Controls \\
\hline Number & 8 & 10 \\
Age & $63 \pm 9$ & $69 \pm 8$ \\
Male/Female & $3 / 5$ & $6 / 4$ \\
Current/ex-smokers & $5 / 3$ & $2 / 7$ \\
Post-BD FEV1\% predicted & $78 \pm 13$ & $95 \pm 17$ \\
GOLD Stage & & - \\
I & 4 & - \\
II & 3 & - \\
III-IV & 1 & - \\
Respiratory Medication & & - \\
SABD & 3 & - \\
LABD & 3 & - \\
ICS & 2 & - \\
Combination (LABD + ICS) & 2 & \\
Theophylline & 0 & - \\
\hline
\end{tabular}

Data are presented as mean \pm SD. BD, bronchodilator; FEV1, forced expiratory volume in $1 \mathrm{~s}$; TLCO, Transfer Factor of the Lung for Carbon Monoxide; SABD, short-acting bronchodilators; LABD, long-acting bronchodilators; ICS, inhaled corticosteroids. 
insulin, $0.1 \mu \mathrm{g} / \mathrm{ml}$ of vitamin A and $0.1 \mu \mathrm{g} / \mathrm{ml}$ of Hydrocortisone. Under sterile conditions, the tissue was sectioned into approximately $1 \mathrm{~mm}$ thick slices and placed on 0.4- $\mu \mathrm{m}$ inserts (Millipore, Bedford, Mass) in different concentrations of CSE $(2.5 \%, 5 \%$ and $10 \%)$, a cytokine combination (labeled as cytokines in Figure 1) consisting of $20 \mathrm{ng} / \mathrm{ml}$ of IL-1 $\beta$, IL- 6 and IL-23 each, or media alone. The explants were incubated in $5 \% \mathrm{CO}_{2} /$ $95 \%$ air at $37^{\circ} \mathrm{C}$ for 3 or 6 hours after which they were processed for protein and RNA.

In separate experiments, we used pharmacological inhibitors against cellular pathways known to contribute to IL-17 expression. Specifically, we used the p38 MAPK inhibitor BIRB796 (0.1 $\mu \mathrm{M}$; Axon Medchem BV, Groningen, The Netherlands) [12], the extracellular signal-regulated kinase (ERK) $1 / 2$ mitogen-activated protein kinase (MAPK) inhibitor PD184352 (2 $\mu \mathrm{M}$; US Biological, Swampscott, MA, USA) [13], the nuclear factor $\kappa B(N F-\kappa B)$ inhibitor helenalin $(1 \mu \mathrm{M}$; Enzo Life Sciences, Ann Arbor, MI, USA) [14], and the phosphoinositide 3kinase (PI3K) inhibitor PI103 (5 $\mu$ M; Cayman Chemical, Ann Arbor, MI, USA) [15]. In each case, explants were incubated with the inhibitor for $1 \mathrm{~h}$ at $37^{\circ} \mathrm{C}$ prior to the CSE or cytokine cocktail. All results were compared to the corresponding vehicle control (DMSO).

\section{Preparation of cigarette smoke extract}

3R4F reference cigarettes with a filter were obtained from the Kentucky Tobacco Research Council (Lexington, KT) and CSE was generated as previously described [16]. An optical density of 0.65 (320 nm) was considered to represent $100 \%$ CSE [16]. This CSE preparation was diluted to the appropriate concentration in BCM.

\section{LDH assay}

Lung tissue explants were cultured with increasing concentrations of CSE (2.5\%, 5\% and 10\%) for $3 \mathrm{~h}, 6 \mathrm{~h}, 12 \mathrm{~h}$ and $24 \mathrm{~h}$. The culture supernatants were collected for lactate dehydrogenase (LDH) detection using a Cytotoxicity LDH Detection Kit (Clontech, Mountain View, CA, USA). The results are presented as OD value and have been corrected by total protein concentration assayed by BCA protein assay kit (Thermo scientific, Rockford, IL, USA).

\section{Western blot}

At the end of exposure, the explants were stored in $-80^{\circ} \mathrm{C}$ with RNA later (Ambion, Grand Island, NY, USA). Tissues were homogenized, lysed, and the lysate $(10 \mu \mathrm{g})$ was loaded on $10 \%$ acrylamide SDS-PAGE NEXT GEL (Amresco, Solon, Ohio), followed by transfer to nitrocellulose membranes (Bio-Rad, Hercules, Calif). The blots were then blocked for $1 \mathrm{~h}$ at room temperature and incubated overnight at $4{ }^{\circ} \mathrm{C}$ with antibodies specific for IL-17A (R\&D Systems, Minneapolis, MN, USA), IL17 F (Santa Cruz Biotechnology, Santa Cruz, Calif) and GAPDH (Millipore, Temecula, USA). After washing (0.1\% Tween-20/PBS), the membranes were incubated with a 1:15,000 dilution of IRDye 800 donkey anti-goat IgG and IRDye 680 goat anti-mouse IgG (Rockland) in blocking buffer and analyzed with an Odyssey IR scanner using Odyssey imaging software 3.0 (LI-COR Biosciences, Inc).

\section{Immunohistochemistry staining}

The immunohistochemistry staining for IL-17A and IL$17 \mathrm{~F}$ (R\&D systems) was performed on paraffin-embedded human lung tissue sections as previously described [17]. Sections were also stained with isotype control $\mathrm{Ab}$ and a primary anti-IL-17A or anti-IL-17 $\mathrm{F}$ Ab was preadsorbed with a 5-fold mass excess of the immunizing peptide (human IL-17A or IL-17 F recombinant protein; R\&D systems) for $1 \mathrm{~h}$ at $4^{\circ} \mathrm{C}$.

\section{Quantitative Reverse Transcription-PCR}

Quantitative RT-PCR for IL-17A, IL-17 F and glyceraldehyde3-phosphate dehydrogenase (GAPDH) was performed as previously described [10]. The IL-17A/F mRNA expression was normalized to GAPDH and compared using the $\delta \delta \mathrm{Ct}$ method. All results were expressed as relative quantity (RQ) compared to medium controls at $3 \mathrm{~h}$ or $6 \mathrm{~h}$.

\section{Statistical analysis}

All data are presented as means \pm SEM. For the results of western blot detecting IL-17A/F expression, statistical analysis was performed using ANOVA followed by the post-hoc Bonferroni test. For the results of Real-time PCR and signaling pathway experiments, statistical analysis was performed using $\mathrm{t}$ test. $\mathrm{P}$ values of less than 0.05 were regarded as statistically significant. Statistical analysis was performed with GraphPad Instat 3 software (GraphPad Software, Inc, La Jolla, Calif).

\section{Results}

\section{Viability of lung tissue explants}

LDH release in culture supernatant is a reliable index of cell injury [18-20], which we used to evaluate tissue viability after cigarette smoke exposure. In non-COPD subjects, no apparent damage was observed in cigarette smoke-exposed tissue compared to that of medium control at any time points examined (Figure 2A). On the contrary, damage occurred in the cigarette smoke exposure conditions from $12 \mathrm{~h}$ time point in tissues from COPD subjects (Medium OD value: $1.8 \pm 0.3$; 5\% CSE OD value: $2.5 \pm 0.7$ ) (Figure $2 B$ ). Thus, we chose shorter time points- including $3 \mathrm{~h}$ and $6 \mathrm{~h}$ - for the remaining studies. 


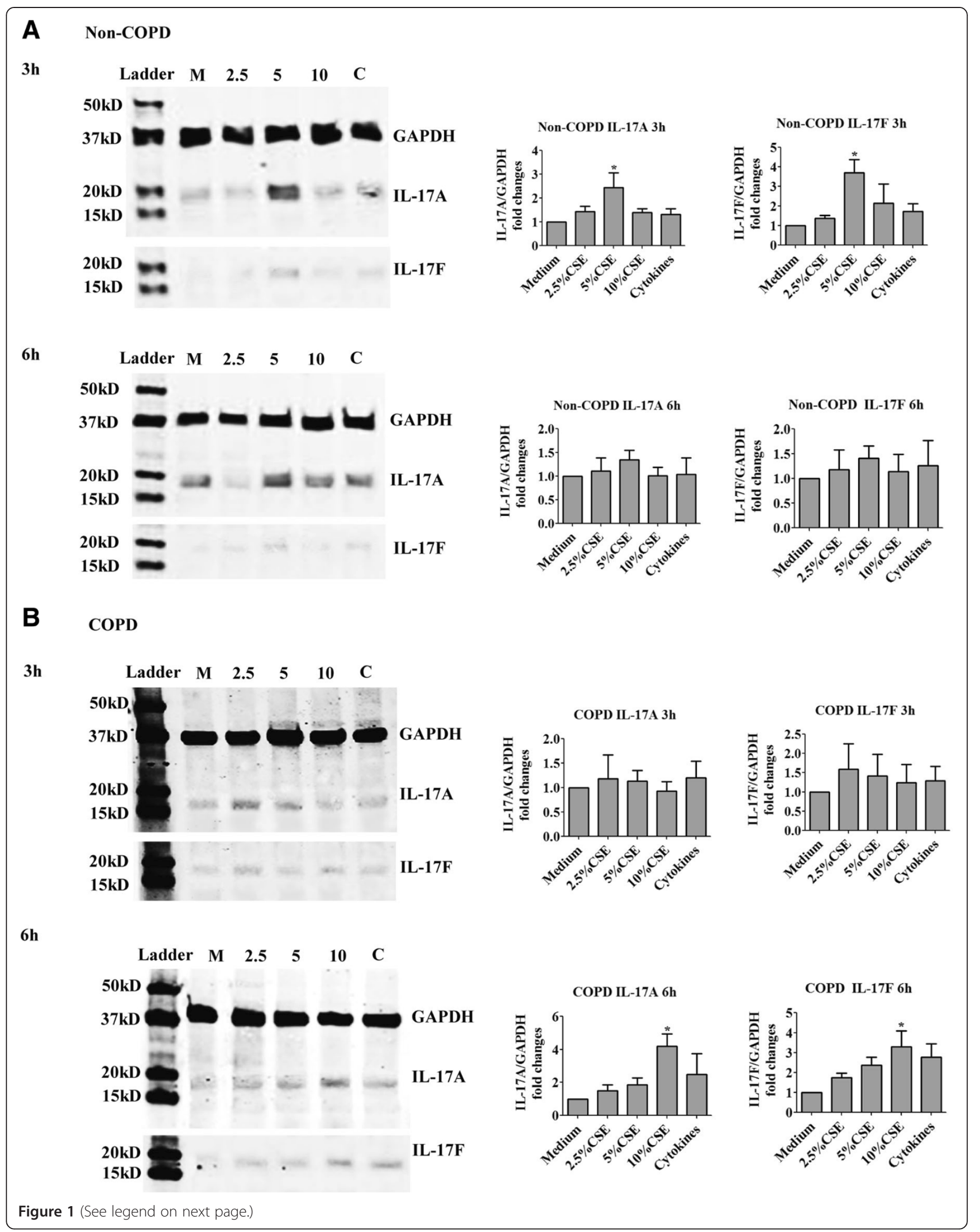


(See figure on previous page.)

Figure 1 Protein expression of IL-17A/F in human lung explants exposed to cigarette smoke extract. Human lung explants from NonCOPD (A) and COPD subjects (B) were cultured with different concentration of cigarette smoke extract for $3 \mathrm{~h}$ or $6 \mathrm{~h}$. The expression of IL-17A/F was detected by western blot. The results are presented as means \pm SEM. The combination of cytokines (labeled as $\mathrm{C}$ ) was used as a control. $\mathrm{N}=$ 10 for Non-COPD subjects and N =8 for COPD subjects. CSE: Cigarette smoke extract. Cytokines: $20 \mathrm{ng} / \mathrm{ml}$ each of IL-1ß, IL-6 and IL-23. ${ }^{*} \mathrm{P}<0.05$ compared with medium control. The label "M", "2.5", "5" and " 10 " represent medium, 2.5\%, 5\% and 10\% of CSE respectively.

\section{IL-17A/F expression in lung tissue}

The protein expression of IL-17A/F in lung tissue explants was first evaluated by western blot. The expression of both IL-17A $(2.4 \pm 0.6$ fold increase, $\mathrm{P}<0.05)$ and $F(3.7 \pm 0.7$ fold increase, $\mathrm{P}<0.05)$ in the tissue from non-COPD subjects was significantly increased after exposure to $5 \%$ of $\mathrm{CSE}$ at $3 \mathrm{~h}$, which returned to baseline by $6 \mathrm{~h}$ (Figure 1A). In lung tissue from COPD subjects, a significant increase in IL-17A/F expression was observed at $6 \mathrm{~h}$ with $10 \%$ of CSE (IL-17A: $4.2 \pm 0.8$ fold increase; IL-17 F: $3.3 \pm 0.8$ fold increase, $\mathrm{P}<0.05$, Figure 1B). Cytokines known to induce Th17 differentiation including IL-1 $\beta$, IL- 6 and IL-23 were used as controls [21,22]. These cytokines did not significantly increase the expression of IL-17A/F of lung explants from either non-COPD or COPD subjects (Figure 1), which may due to the impaired effect of these cytokines on the structural cells.

IL-17A and IL-17 F can be produced by both immune cells and structural cells $[23,24]$. Our finding that production of these cytokines is increased in cultured lung slices exposed to CSE, raises the question as to which cells are responsible for this increased expression. Using immunohistochemistry staining to identify the source of IL-17A/F in explants, we observed that both local structural and immune cells expressed IL-17A/F (Figure 3). The arrow in the picture Non-COPD medium indicates the expression of IL-17 F in the local immune cells of lung tissue. The absence of color may indicate the low expression of IL-17 F in these cells without CSE stimulation, while it appeared with CSE stimulation. This finding suggests that CSE induces IL-17A/F expression from lung parenchyma under the absence of systemic immune cell recruitment.

The mRNA expression of IL-17A/F in lung tissue explants under optimal CSE concentration and exposure time (Non-COPD: $5 \%$ of CSE for $3 \mathrm{~h}$; COPD: $10 \%$ of CSE for $6 \mathrm{~h}$ ) was examined by real-time PCR. The IL-17A/F mRNA expression was also significantly elevated as those observed on protein level (Figure 4). These results suggest that the elevated IL-17A/F expression under CSE exposure occurred at the transcriptional level.

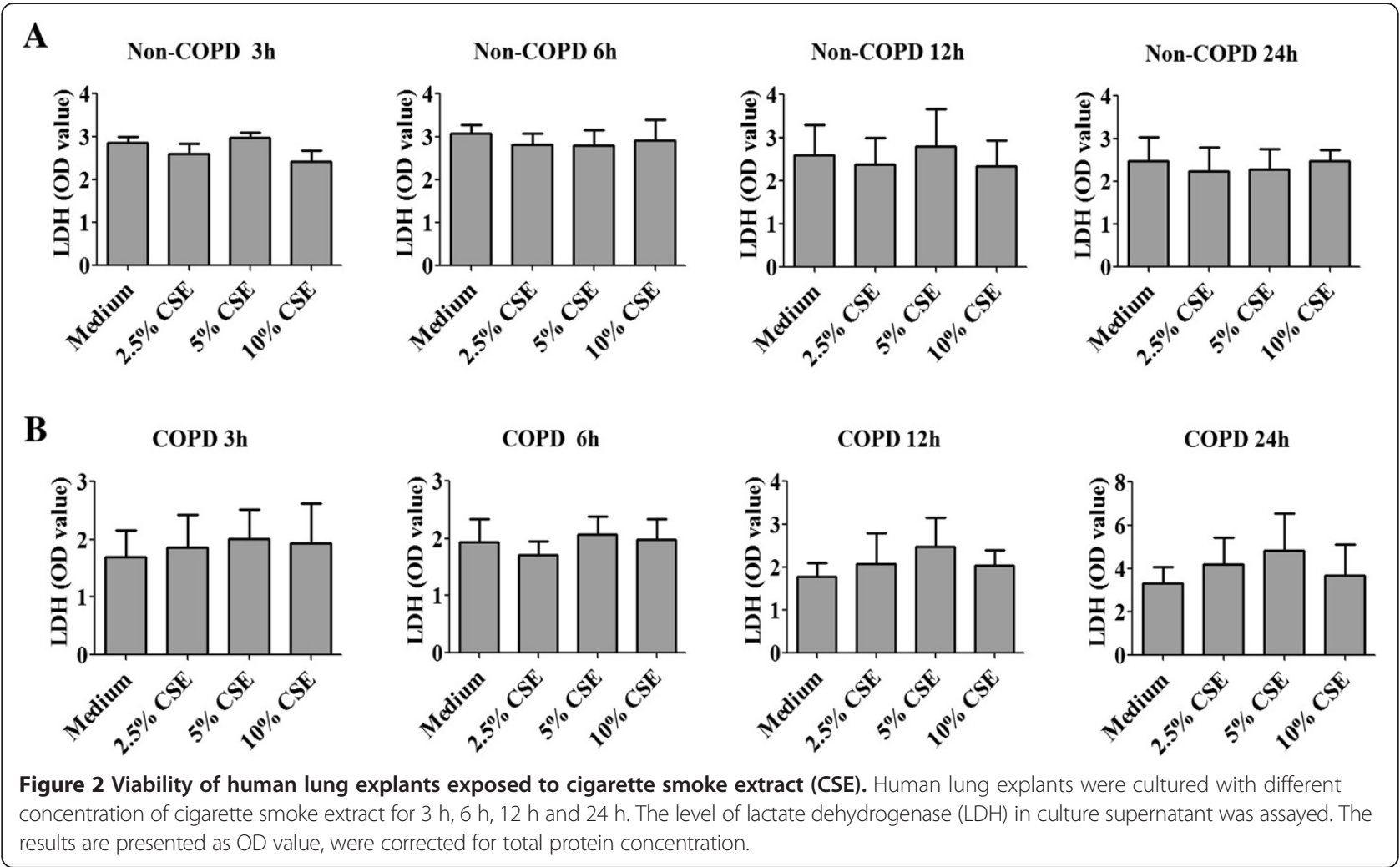




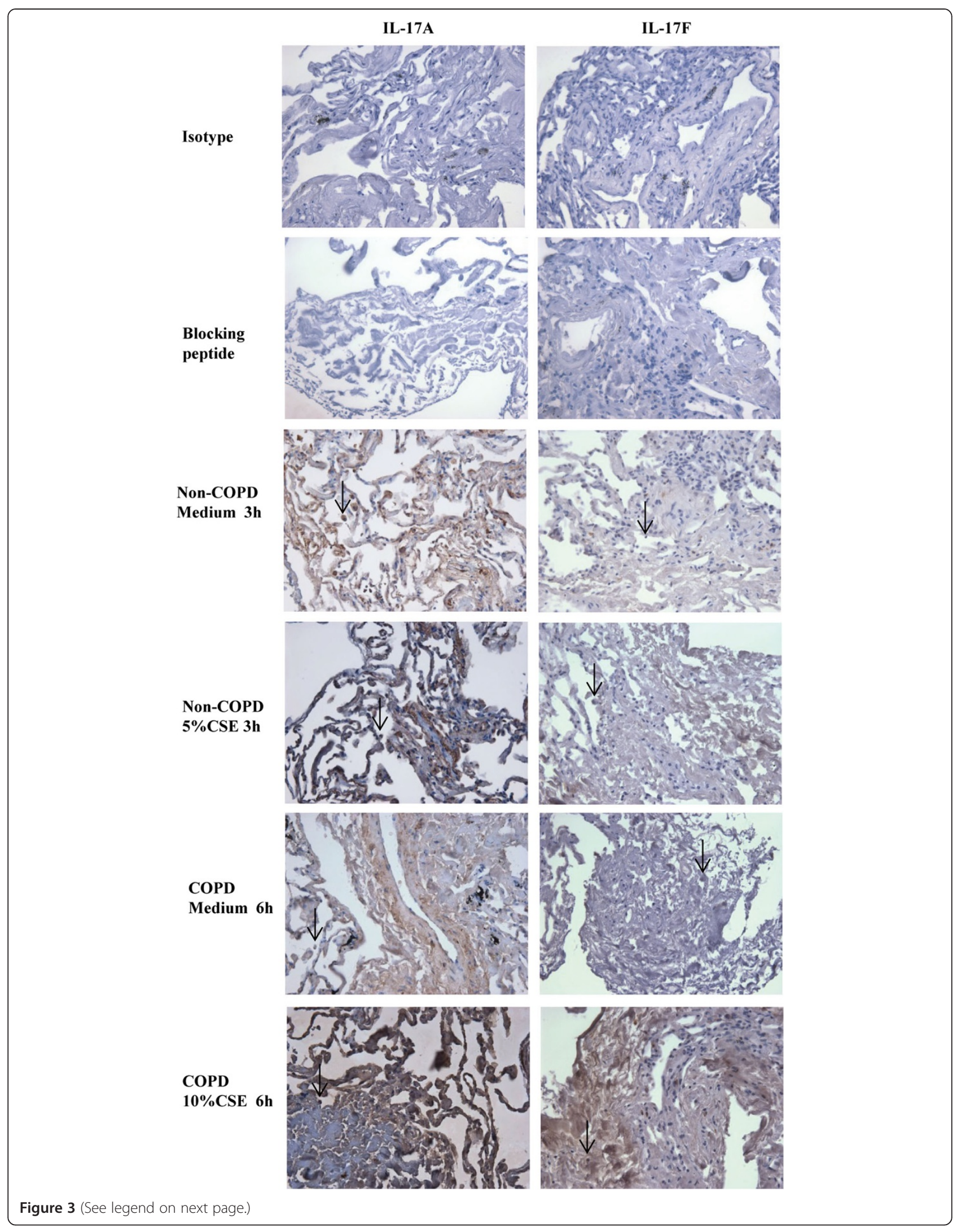


(See figure on previous page.)

Figure 3 Immunohistochemistry staining for IL-17A/F in human lung explants exposed to cigarette smoking medium. Human lung explants from Non-COPD and COPD subjects were cultured with $5 \%$ or $10 \%$ of CSE for $3 \mathrm{~h}$ or $6 \mathrm{~h}$ respectively. Brown color staining represents the positive signal for IL-17A/F. The arrows indicate the local immune cells in the lung tissue. Representative images from 5 Non-COPD and 4 COPD subjects are shown. Magnification: 400X.

\section{Signaling pathways involved in CSE-induced IL-17 A/F expression}

We next examined the signaling pathway involved in the elevated IL-17A/F expression of lung tissue explants from Non-COPD subjects with CSE exposure. The specific pharmacological inhibitor for MAPK p38, ERK1/2, NF- $\mathrm{KB}$ and PI3K pathways was used. These inhibitors did not cause the toxicity of tissue, which was examined by LDH level in the culture supernatant (data not shown). The protein expression of IL-17A/F was evaluated by western blot. The inhibitors for NF-kB (Helenalin) and PI3K (PI-103) significantly attenuated CSE-induced IL-17A (DMSO: $3.1 \pm 1.2$ folds; Helenalin: $0.7 \pm 0.2$ fold, $\mathrm{P}<0.05$; PI-103: $1.0 \pm 0.3$ fold, $\mathrm{P}<0.05)$ and IL-17 F (DMSO: $2.0 \pm 0.2$ folds;
Helenalin: $1.2 \pm 0.2$ fold, $\mathrm{P}<0.01$; PI-103: $1.1 \pm 0.3$ fold, $\mathrm{P}<0.05)$ expression from lung tissue of non-COPD subjects (Figure 5). However inhibition of p38 (BIRB796) and ERK1/2 (PD184352) failed to reduce IL-17A/F expression induction by CSE. Interestingly, the MAPK p38 inhibitor BIRB796 significantly enhanced CSE-induced IL-17 F expression $(3.9 \pm 0.7$ folds, $\mathrm{P}<0.05$ compared with $\mathrm{DMSO}$, Figure 5). These results suggest that both NF-KB and PI3K pathway are involved in CSE-induced IL-17A/F expression from the lung tissue explants.

\section{Discussion}

In the present study, we investigated the expression of IL-17A/F in explants of human lung tissue obtained

\section{A Non-COPD}

\section{IL-17A 3h}

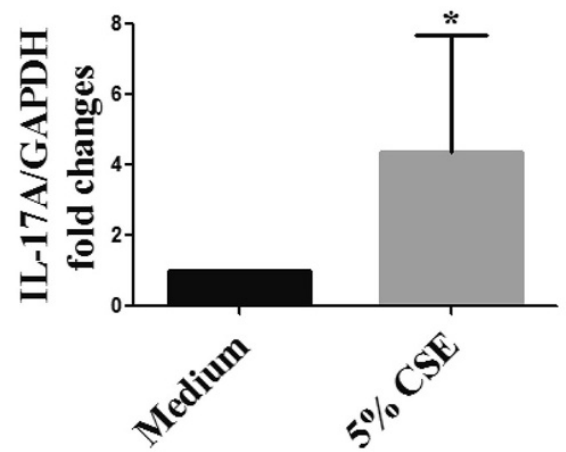

\section{B COPD}

IL-17A 6h

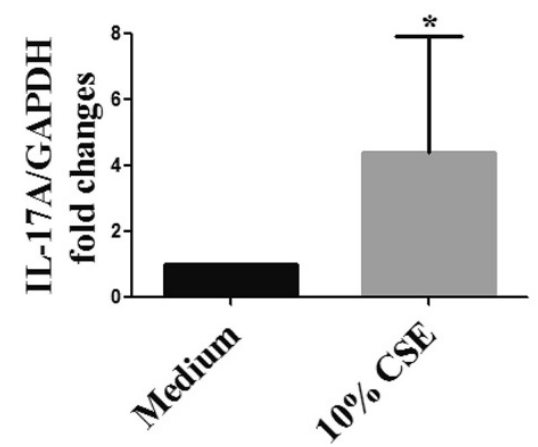

IL-17F 3h

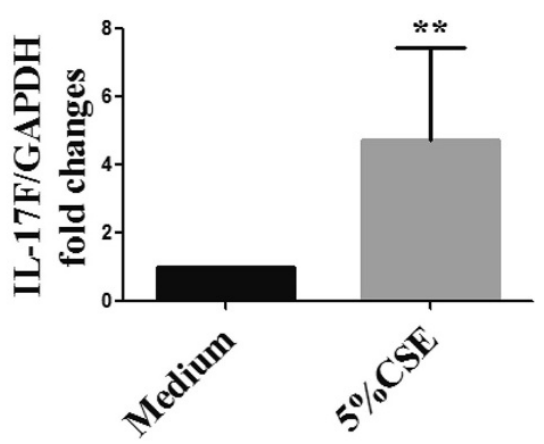

IL-17F 6h

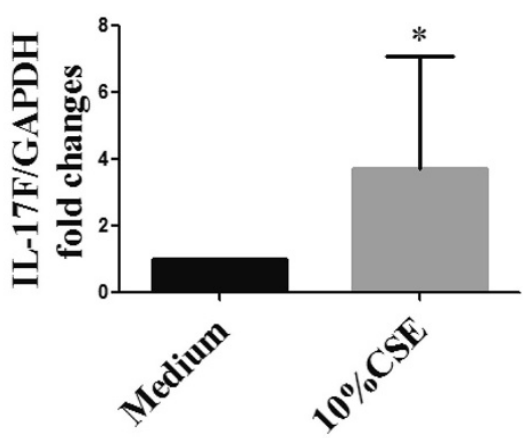

Figure 4 mRNA expression of IL-17A/F in human lung explants exposed to cigarette smoking medium. (A) Human lung explants from Non-COPD subjects were cultured with $5 \%$ of CSE for $3 \mathrm{~h}$. $\mathrm{N}=10$ subjects. (B) Human lung explants from COPD subjects were cultured with $10 \%$ of CSE for 6 h. $N=8$ subjects. The mRNA expression of IL-17A/F was detected by real-time PCR. CSE: Cigarette smoke. ${ }^{*} \mathrm{P}<0.05$, ${ }^{* *} \mathrm{P}<0.01$ compared with medium control. 


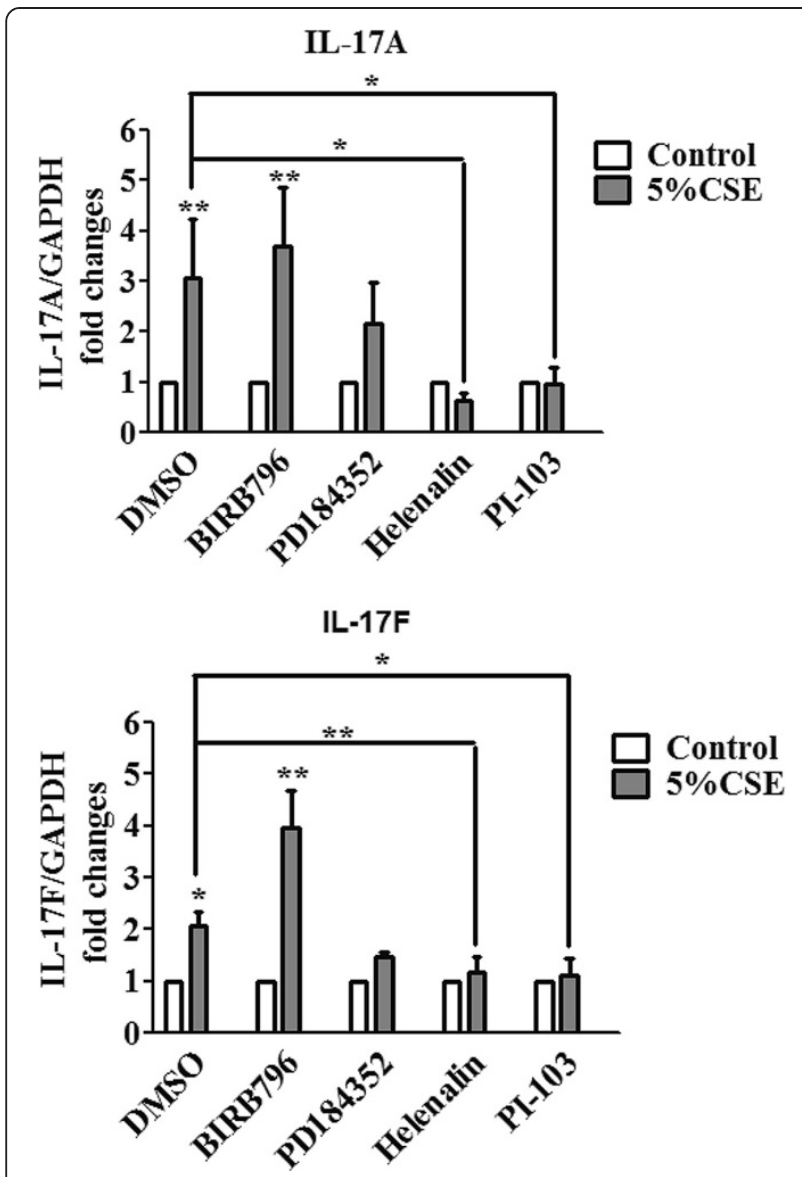

Figure 5 Signaling pathways involved in CSE-induced IL-17 A/F expression from human lung explants. The explants were incubated with the p38 MAPK inhibitor BIRB796 $(0.1 \mu \mathrm{M})$, the ERK1/2 inhibitor PD184352 $(2 \mu \mathrm{M})$, the NF-KB inhibitor helenalin $(1 \mu \mathrm{M})$, and the PI3K inhibitor PI103 $(5 \mu \mathrm{M})$ for $1 \mathrm{~h}$ at $37^{\circ} \mathrm{C}$ prior to the exposures. The explants from Non-COPD subjects were cultured with $5 \%$ of cigarette smoke extract (CSE) for $3 \mathrm{~h}$. All results were compared to the corresponding vehicle control DMSO. The results are presented as means \pm SEM. $N=7$ subjects. ${ }^{*} \mathrm{P}<0.05,{ }^{* *} \mathrm{P}<0.01$

from subjects with and without COPD. We found evidence that the expression of both IL-17A and IL-17 F is increased by the cigarette smoke exposure in explants from both non-COPD and COPD subjects. The local cells of lung tissue contributed to the heightened expression of these cytokines under the cigarette smoke exposure conditions. These observations add to the growing evidence which suggests that Th17 cytokines play a significant role in this disease.

We found parenchymal tissue from non-COPD subjects more rapidly induced IL-17A/F (at $3 \mathrm{~h}$ ) in response to cigarette smoke, and that lower concentrations of CSE (5\%) contributed to this induction. Contrary to this, a higher concentration of CSE (10\%) and longer exposure times $(6 \mathrm{~h})$ were necessary to significantly elevate IL-17A/F expression in explants from COPD patients
(Figure 1). This suggests that in COPD patients, the lung tissue and cells may have weaker ability to secrete significant levels of cytokines, which has been shown in our previous study concerning the secretary phenotype of $\mathrm{CD}^{+} \mathrm{T}$ cells in COPD patients [25]. All these may reflect the epigenetic changes in COPD that have led to phenotypic changes altering the responsiveness of cells. Another possibility contributing to the delayed expression of IL-17A/F in lung tissue from COPD subjects responded to CSE might lie in the interference from intrinsically increased oxidative stress in lung tissue under COPD status. In lung tissue of COPD subjects, the oxidant stress is increased [26], while a recent study showed that transient exposure to oxidative stress temporally could delay the activation of NF- $\mathrm{kB}$ [27], one of the signaling pathway involved in the IL-17A/F expression induced by CSE in the present study. Thus we suspect that the delayed expression of IL-17A/F in lung tissue of COPD subjects might due to the delayed NF- $\mathrm{kB}$ activation induced by increased oxidative stress.

A smoking-induced inflammatory reaction in the airways and lung parenchyma comprises neutrophils, alveolar macrophages and $\mathrm{T}$ cells, predominantly $\mathrm{CD} 8^{+} \mathrm{T}$ cells [28]. All of the aforementioned cells are the potential resource of IL-17 [5]. Parenchyma from COPD patients have more recruited cells (including $\mathrm{T}$ cells, monocytes and dendritic cells) and less structural cells (alveolar epithelial cells) than non-COPD tissue. However in this study we exposed the lung tissue explants to CSE and used the medium condition as the controls. Thus under the environment without intact circulation (no more cells will be recruited), the effect of CSE exposure on IL-17A/F expression in lung tissue was able to be observed. Nevertheless, the recruited immune cells in lung tissue of COPD patients have been restrained in explants and may contribute to the elevated production of IL-17A/F. In the present study, we demonstrated for the first time that CSE exposure could induce IL-17A/F expression from lung parenchyma in the absence of systemic immune cell recruitment, suggesting that CSE promotes expression of these cytokines in local lung cells. The notion that both local lung immune and structural cells could be important sources of IL-17 is supported by our recent publication demonstrating that CSE exposure enhanced IL-17A expression from mouse lung epithelial cells (MLE-12 cells), a distal bronchiolar and alveolar epithelial cell line [17]. Furthermore, more studies have shown that IL-17 is expressed by structural cells especially by epithelial cells. For example, IL-17 is expressed by tubular epithelial cells in renal transplant recipients [23], and IL-17 production has been described by Paneth cells, highly specialized epithelial cells of the small intestine [29].

We also explored the signaling pathways involved in CSE-induced IL-17A/F expression from lung explants. 
Cellular signaling pathways previously implicated in IL17 production include the p38 MAPK [30], ERK1/2 MAPK [31], NF-KB and PI3K [32]. We found the IL$17 \mathrm{~A} / \mathrm{F}$ expression is dependent on both the NF- $\mathrm{KB}$ and PI3K pathways (Figure 5). The involvement of NF- $\kappa B$ and PI3K pathways in IL-17 induction has been shown in other inflammatory diseases like asthma [33] and rheumatoid arthritis [32], where IL-17 may play important pathogenic roles. It is noteworthy that the administration of p38 MAPK inhibitor BIRB796 enhanced CSE-induced IL-17A/F expression (Figure 5). This might be explained by the enhanced activity of NF- $\mathrm{kB}$ or PI3K pathway when p38 MAPK is inhibited. It has been reported that the p38 MAPK inhibitor SB203580 enhances NF-kB transcriptional activity via the ERK pathway [34].

\section{Conclusions}

In conclusion, we demonstrated the direct effect of cigarette smoke on IL-17A/F expression from human lung parenchymal tissue by using an ex-vivo explant culture system. It indicates that elevated IL-17A/F in COPD is the product from not only the increased number of recruited inflammatory cells but also by the heightened expression of these cytokines in the local cells under the cigarette smoke exposure conditions. Thus, future exploration focusing on IL-17-targeted therapies in COPD is warranted.

\begin{abstract}
Abbreviations
COPD: Chronic obstructive pulmonary disease; CSE: Cigarette smoke extract; MAPK: Mitogen-activated protein kinase; ERK: Extracellular signal-regulated kinase; PI3K: Phosphoinositide 3-kinase.
\end{abstract}

\section{Competing interests}

The authors declare that they have no competing interests.

\section{Authors' contributions}

YC carried out explant cultures and data analysis and drafted the manuscript. LA performed signaling experiments and Western blot. SA (Sama Alshakfa) participated in Western blot and carried out RT-PCR. SA (Severine Audusseau) participated in explant cultures and sample collection. AKM participated in sample collection. FC performed immunohistochemistry staining. PN, CJB and $\mathrm{QH}$ participated in the design of the study and corrected the manuscript. DHE supervised of the study and corrected the manuscript. All authors read and approved the final manuscript.

\section{Acknowledgements}

This study was supported by a grant from the Collaborative Innovation Research Fund Program of GSK; YC was supported by the Fundamental Research Funds for the Central Universities; PN was supported by a Canada Research Chair in Airway Inflammometry; CJB was supported by a salary award from the Fonds de recherche du Quebec-Sante (FRQ-S).

\section{Author details}

'Meakins-Christie Laboratories and Respiratory Division, McGill University Health Centre and Department of Medicine, McGill University, Montreal, Quebec, Canada. ${ }^{2}$ Center for Translational Medicine, The Key Laboratory of Biomedical Information Engineering of Ministry of Education, School of Life Science and Technology and Frontier Institute of Science and Technology, Xi'an Jiaotong University, Xi'an, China. ${ }^{3}$ Firestone Institute for Respiratory Health, St. Joseph's Healthcare and Department of Medicine, McMaster University, Hamilton, Ontario, Canada.
Received: 18 July 2014 Accepted: 4 November 2014

Published online: 27 November 2014

\section{References}

1. Pauwels RA, Rabe KF: Burden and clinical features of chronic obstructive pulmonary disease (COPD). Lancet 2004, 364:613-620.

2. Cosio MG, Saetta M, Agusti A: Immunologic aspects of chronic obstructive pulmonary disease. N Engl J Med 2009, 360:2445-2454.

3. Agusti A, MacNee W, Donaldson K, Cosio M: Hypothesis: does COPD have an autoimmune component? Thorax 2003, 58:832-834.

4. Morissette MC, Jobse BN, Thayaparan D, Nikota JK, Shen P, Labiris NR, Kolbeck R, Nair P, Humbles AA, Stampfli MR: Persistence of pulmonary tertiary lymphoid tissues and anti-nuclear antibodies following cessation of cigarette smoke exposure. Respir Res 2014, 15:49.

5. Kramer JM, Gaffen SL: Interleukin-17: a new paradigm in inflammation, autoimmunity, and therapy. J Periodontol 2007, 78:1083-1093.

6. Fujisawa $T$, Velichko $S$, Thai $P$, Hung $L Y$, Huang $F$, Wu R: Regulation of airway MUC5AC expression by IL-1 beta and IL-17A; the NF-kappaB paradigm. J Immunol 2009, 183:6236-6243.

7. Park H, Li Z, Yang XO, Chang SH, Nurieva R, Wang YH, Wang Y, Hood L, Zhu Z, Tian Q, Dong C: A distinct lineage of CD4 T cells regulates tissue inflammation by producing interleukin 17. Nat Immunol 2005, 6:1133-1141.

8. Di Stefano A, Caramori G, Gnemmi I, Contoli M, Vicari C, Capelli A, Magno F, D'Anna SE, Zanini A, Brun P, Casolari P, Chung KF, Barnes PJ, Papi A, Adcock I, Balbi B: T helper type 17-related cytokine expression is increased in the bronchial mucosa of stable chronic obstructive pulmonary disease patients. Clin Exp Immunol 2009, 157:316-324.

9. Cosio MG: Autoimmunity, T-cells and STAT-4 in the pathogenesis of chronic obstructive pulmonary disease. Eur Respir J 2004, 24:3-5.

10. Chang Y, Nadigel J, Boulais N, Bourbeau J, Maltais F, Eidelman DH, Hamid Q: CD8 positive T cells express IL-17 in patients with chronic obstructive pulmonary disease. Respir Res 2011, 12:43.

11. Resau JH, Sakamoto K, Cottrell JR, Hudson EA, Meltzer SJ: Explant organ culture: a review. Cytotechnology 1991, 7:137-149.

12. Kuma Y, Sabio G, Bain J, Shpiro N, Marquez R, Cuenda A: BIRB796 inhibits all p38 MAPK isoforms in vitro and in vivo. J Biol Chem 2005, 280:19472-19479.

13. Robins S, Roussel L, Schachter A, Risse PA, Mogas AK, Olivenstein R, Martin JG, Hamid Q, Rousseau S: Steroid-insensitive ERK1/2 activity drives CXCL8 synthesis and neutrophilia by airway smooth muscle. Am J Respir Cell Mol Biol 2011, 45:984-990.

14. Seidel P, Merfort I, Hughes JM, Oliver BG, Tamm M, Roth M: Dimethylfumarate inhibits NF-\{kappa\}B function at multiple levels to limit airway smooth muscle cell cytokine secretion. Am J Physiol Lung Cell Mol Physiol 2009, 297:L326-L339.

15. Gursel DB, Connell-Albert YS, Tuskan RG, Anastassiadis T, Walrath JC, Hawes $\mathrm{J}$, Amlin-Van Schaick JC, Reilly KM: Control of proliferation in astrocytoma cells by the receptor tyrosine kinase/PI3K/AKT signaling axis and the use of PI-103 and TCN as potential anti-astrocytoma therapies. Neuro Oncol 2011, 13:610-621.

16. Baglole CJ, Maggirwar SB, Gasiewicz TA, Thatcher TH, Phipps RP, Sime PJ: The aryl hydrocarbon receptor attenuates tobacco smoke-induced cyclooxygenase- 2 and prostaglandin production in lung fibroblasts through regulation of the NF-kappaB family member RelB. J Biol Chem 2008, 283:28944-28957.

17. Chang Y, Al-Alwan L, Audusseau S, Chouiali F, Carlevaro-Fita J, Iwakura Y, Baglole CJ, Eidelman DH, Hamid Q: Genetic deletion of IL-17A reduces cigarette smoke-induced inflammation and alveolar type II cell apoptosis. Am J Physiol Lung Cell Mol Physiol 2014, 306:L132-143.

18. Porro GA, Lee JH, de Azavedo J, Crandall I, Whitehead T, Tullis E, Ganz T, Liu $M$, Slutsky AS, Zhang H: Direct and indirect bacterial killing functions of neutrophil defensins in lung explants. Am J Physiol Lung Cell Mol Physiol 2001, 281:L1240-L1247.

19. Martin WJ 2nd, Gadek JE, Hunninghake GW, Crystal RG: Oxidant injury of lung parenchymal cells. J Clin Invest 1981, 68:1277-1288.

20. Muller B, Hochscheid R, Seifart C, Barth PJ: Alpha-tocopherol improves impaired physiology of rat type II pneumocytes isolated from experimentally injured lungs. Eur J Clin Invest 2000, 30:1018-1026.

21. Wilson NJ, Boniface K, Chan JR, McKenzie BS, Blumenschein WM, Mattson JD, Basham B, Smith K, Chen T, Morel F, Lecron JC, Kastelein RA, Cua DJ, McClanahan TK, Bowman EP, de Waal Malefyt R: Development, cytokine 
profile and function of human interleukin 17-producing helper T cells. Nat Immunol 2007, 8:950-957.

22. Acosta-Rodriguez EV, Napolitani G, Lanzavecchia A, Sallusto F: Interleukins 1 beta and 6 but not transforming growth factor-beta are essential for the differentiation of interleukin 17-producing human T helper cells. Nat Immunol 2007, 8:942-949.

23. Loverre A, Tataranni T, Castellano G, Divella C, Battaglia M, Ditonno P, Corcelli M, Mangino M, Gesualdo L, Schena FP, Grandaliano G: IL-17 expression by tubular epithelial cells in renal transplant recipients with acute antibody-mediated rejection. Am J Transplant 2011, 11:1248-1259.

24. Cua DJ, Tato CM: Innate IL-17-producing cells: the sentinels of the immune system. Nat Rev Immunol 2010, 10:479-489.

25. Nadigel J, Prefontaine D, Baglole CJ, Maltais F, Bourbeau J, Eidelman DH, Hamid Q: Cigarette smoke increases TLR4 and TLR9 expression and induces cytokine production from CD8(+) T cells in chronic obstructive pulmonary disease. Respir Res 2011, 12:149.

26. Kirkham P, Rahman I: Oxidative stress in asthma and COPD: antioxidants as a therapeutic strategy. Pharmacol Ther 2006, 111:476-494.

27. Lee $Y$, Choi J, Ha KH, Jue DM: Transient exposure to hydrogen peroxide inhibits the ubiquitination of phosphorylated IkappaBalpha in TNFalphastimulated HEK293 cells. Exp Mol Med 2012, 44:513-520.

28. Cosio MG, Majo J: Inflammation of the airways and lung parenchyma in COPD: role of T cells. Chest 2002, 121:160S-165S.

29. Takahashi N, Vanlaere I, de Rycke R, Cauwels A, Joosten LA, Lubberts E, van den Berg WB, Libert C: IL-17 produced by Paneth cells drives TNFinduced shock. J Exp Med 2008, 205:1755-1761.

30. Noubade R, Krementsov DN, Del Rio R, Thornton T, Nagaleekar V, Saligrama N, Spitzack A, Spach K, Sabio G, Davis RJ, Rincon M, Teuscher C: Activation of p38 MAPK in CD4 T cells controls IL-17 production and autoimmune encephalomyelitis. Blood 2011, 118:3290-3300.

31. Brereton CF, Sutton CE, Lalor SJ, Lavelle EC, Mills KH: Inhibition of ERK MAPK suppresses IL-23- and IL-1-driven IL-17 production and attenuates autoimmune disease. J Immunol 2009, 183:1715-1723.

32. Kim KW, Cho ML, Park MK, Yoon CH, Park SH, Lee SH, Kim HY: Increased interleukin-17 production via a phosphoinositide 3-kinase/Akt and nuclear factor kappaB-dependent pathway in patients with rheumatoid arthritis. Arthritis Res Ther 2005, 7:R139-R148.

33. Park SJ, Lee KS, Kim SR, Min KH, Moon H, Lee MH, Chung CR, Han HJ, Puri KD, Lee YC: Phosphoinositide 3-kinase delta inhibitor suppresses interleukin-17 expression in a murine asthma model. Eur Respir J 2010, 36:1448-1459.

34. Birkenkamp KU, Tuyt LM, Lummen C, Wierenga AT, Kruijer W, Vellenga E: The p38 MAP kinase inhibitor SB203580 enhances nuclear factor-kappa $B$ transcriptional activity by a non-specific effect upon the ERK pathway. Br J Pharmacol 2000, 131:99-107.

doi:10.1186/s12931-014-0145-7

Cite this article as: Chang et al.: Upregulation of IL-17A/F from human

lung tissue explants with cigarette smoke exposure: implications for COPD. Respiratory Research 2014 15:145.

\section{Submit your next manuscript to BioMed Central and take full advantage of:}

- Convenient online submission

- Thorough peer review

- No space constraints or color figure charges

- Immediate publication on acceptance

- Inclusion in PubMed, CAS, Scopus and Google Scholar

- Research which is freely available for redistribution 